\title{
Effect of Board Members' Gender on Corporate Social Responsiveness Orientation
}

Dr. Nabil A. Ibrahim, Management, Augusta College

Dr. John P. Angelidis, Management, St. John's University

\begin{abstract}
This study examines the relationship between board members'gender and their corporate social responsiveness orientation. An empirical analysis of survey data from 398 corporate directors shows that, compared to their male counterparts, female directors exhibit a stronger orientation toward the discretionary component of corporate responsibility. Male board members, in contrast to female directors, are more concerned about economic performance. Results further reveal no significant differences between the two genders with respect to both the legal and ethical dimensions.
\end{abstract}

\section{Introduction}

According to corporate law, publicly traded corporations are required to have boards of directors. The directors have the legal authority for controlling and maintaining organizational operation and effectiveness ${ }^{7}$. As the stockholders' formal representatives, board members bear the ultimate responsibility for supervising management's performance.

However, the recent takeover battles involving some of the largest corporations, along with the increased risks of personal legal liability, have resulted in a growing concern over the role and functions of the board's members. More recently, the Savings and Loan crisis has raised important questions regarding the board's level of involvement and its ethical and social responsibilities in corporate decision making ${ }^{23}$.

A number of writers have expressed the need to study upper echelon characteristics in order to understand an organization's strategic processes ${ }^{24}$. Hambrick and Mason (1984) have proposed a number of hypotheses for testing the relationship between organizational outcomes and certain demographic characteristics of top executives. They assert that strategic decisions reflect the background of the organization's most powerful managers and what the organization does could be explained, at least in part, by the profile of its upper echelon.

Consistent with this view, a relatively small body of literature has focused on the effect of the background characteristics of one segment of the firm's upper echelon - its board of directors - on such areas as company performance ${ }^{28},{ }^{36}$, corporate social responsiveness $^{27}$, board committee membership ${ }^{19}$, CEO succes$\operatorname{sion}^{21}$, and board members' involvement in the strategic management process ${ }^{17}$. Yet, in spite of this increased attention, there is still one area about which little is known - the possible impact of a member's gender on the strategic management of the firm.

The present study was designed to investigate such a possibility. Specifically, we designed the study to determine whether a relationship existed between board members' gender and their corporate social responsiveness orientation.

\section{Directors' Gender}

A number of studies of female directors have been published in recent years ${ }^{1},{ }^{14}$. They show that while the number of female directors is growing ${ }^{8},{ }^{34}$, their overall percentage continues to be rather small ${ }^{32}, 8$. For example, in 1986 women held "only $3 \%$ to $4 \%$ of Fortune 1,000 directorships despite their majority place in the workforce ${ }^{2} . "$

Critics have charged that the preponderance of male directors on corporate boards may be due to the perception, on the part of many, that women are "a piece of fluff with no depth"30 and therefore are asked to serve on boards as a token to enhance a company's image ${ }^{34}$. However, in a recent survey of 250 companies, Kesner (1988) found that female directors are just as likely to 
serve on the major board committees as their male counterparts.

\section{Corporate Social Responsiveness Orientation (CSRO)}

Research regarding the relationship between corporate social responsibility and financial performance has increased dramatically in recent years. Yet, in spite of this increased attention, one area about which very little is known concerns the relationship between board composition and CSRO. Zahra and Stanton (1988) found that outsider dominated boards exhibit greater social responsiveness. On the other hand, Kesner, Victor and LaMont (1986) showed that, when poor social performance was measured by the number of corporate illegal acts, outsider domination was not related to improved social performance. In a multivariate investigation of member characteristics, O'Neill, Saunders and McCarthy (1989) found that a director's age, education, and financial stake in the firm are positively related to increased levels of CSRO. However, no correlation was found between the level of CSRO and length of time on the board, socioeconomic background, educational background, and career background. Thus, although the relationship between several background characteristics and CSRO has been examined, to date no linkages have been developed to connect the level of CSRO to a board member's gender.

\section{Methodology}

Sample

The Standard and Poor's Register of Corporations, Directors and Executives formed the pool from which members were identified. Since a relatively small percentage of women serve on boards of directors, a stratified sampling technique was employed. Of the 1300 questionnaires which were sent, 800 were mailed to male directors and 500 were mailed to female directors. A first mailing and two follow-up mailings generated 398 $(30.6 \%)$ usable responses. Because the response rate compares favorably with similar studies of upper echelons $^{3},{ }^{35}$, we did not consider tests of non-response bias necessary.

\section{Measures}

A questionnaire was developed to measure the variables of interest. Respondents were asked to indicate their gender and the firm's industry. CSRO was measured with an instrument developed by Aupperle, Carroll and Hatfield (1985). It is based on the four-part construct proposed by Carroll (1979). In his seminal paper on the obligations of business toward society, Carroll suggested that business firms have four major types of social responsibilities: economic, legal, ethical, and discretionary. The first component requires the firm to maximize profits for the owners by efficiently providing a supply of goods and services to meet market demands. Legal responsibility requires the firm to operate within the confines of the law and the legal environment. To be ethical, a decision maker should behave in ways that conform and promote society's norms and values and act with fairness, equity, and impartiality. Finally, discretionary activities are purely voluntary and guided by a firm's desire to make social or philanthropic contributions not mandated by economics, law, or ethics.

The instrument adopted a forced-choice format to minimize the social desirability of responses. Respondents were asked to allocate up to 10 points among four statements in each of several sets of statements. Each of the four statements in a set represents a different underlying dimension of Carroll's four components economic, legal, ethical, and discretionary responsibilities. The instrument used in this study contained 20 such statements. The scores on each of the four dimensions were summed to arrive at a respondent's orientation toward each of the four components.

\section{Analysis and Results}

The respondents served on the boards of the following industries: Services (22\%), manufacturing (20\%), financial $(16 \%)$, retail trade $(15 \%)$, transportation and communications $(10 \%)$, wholesale trade $(7 \%)$, and communications (1\%). Interestingly, the response rates for the female and male directors were almost identical (31 and 30 percent, respectively).

Table 1 contains the matrix of the dependent variables' zero-order correlation coefficients, means, standard deviations, and reliability coefficients. All of the dimensions were negatively correlated with each other except for the ethical and legal dimensions. Also, the highest correlation was between the economic and ethical components. Results in this table are very similar to those reported by Aupperle et al. (1985) and Smith and Blackburn (1988). Alpha coefficients, ranging from .84 to .92 , were high thus reinforcing the reliability of the four constructs ${ }^{26}$.

The analysis was conducted in two stages. First, we considered a multivariate analysis of variance (MANOVA) procedure to be the most appropriate analytic technique for exploring differences between the two groups. This procedure compensates for variable intercorrelation and provides an omnibus test of any multivariate effect. Using an approximate F-statistic based on the Wilks-lambda criterion ${ }^{12}$, the MANOVA resulted in an F-value of 17.23, significant beyond the .001 level. From this test, we concluded that there were significant differences between the two groups. That is, the CSRO of male board members was significantly different from 
Table 1

Means, Standard Deviations, Reliability Coefficients, and Intercorrelations of all Dependent Variables ${ }^{a}$

\begin{tabular}{|c|c|c|c|c|c|c|}
\hline Variables & Means & $\begin{array}{l}\text { Standard } \\
\text { Deviations }\end{array}$ & $\begin{array}{l}\text { Reliability } \\
\text { Coefficients }\end{array}$ & $\mathrm{s}^{\mathrm{b}} 1$ & 2 & 3 \\
\hline 1. Economic & 3.42 & 0.77 & 0.89 & & & \\
\hline 2. Legal & 2.61 & 0.58 & 0.92 & $-.29 *$ & & \\
\hline 3. Ethical & 2.33 & 0.57 & 0.84 & $-.58 *$ & 0.11 & \\
\hline 4. Philanthropic & 1.59 & 0.50 & 0.87 & $-.43 *$ & $-0.33 *$ & -0.19 \\
\hline $\begin{array}{l}\mathrm{a}_{\mathrm{N}}=398 \\
\mathrm{~b}_{\mathrm{Cronbach}} \mathrm{s} \text { alpha } \\
\star \mathrm{p}<.01 \\
\star * \mathrm{p}<.05\end{array}$ & & & & & & \\
\hline
\end{tabular}

that of their female counterparts.

Next, to understand the underlying contributions of the variables to the significant multivariate effect, we computed means and conducted univariate analyses of variance (ANOVAs) for the two groups. As shown in Table 2, these results show that differences between the two groups were significant on two of the variables. Specifically, the mean scores on the economic component were 3.02 for the women and 3.67 for the men. Mean scores on the legal dimension were 2.64 for the women and 2.59 for the men. On the ethical dimension, the scores were 2.38 and 2.29 , respectively. Finally, the women's mean score on the discretionary component was 1.83 while the men's mean score was 1.43 .

From the univariate ANOVAs, we see that important differences existed between the two groups with respect to the economic $\left(\mathrm{F}_{1,396}=78.63, \mathrm{p}<.0001\right)$ and discretionary components $\left(\mathrm{F}_{1,396}=82.30, \mathrm{p}<.0001\right)$ of the CSRO scale. Compared to their male counterparts, female directors exhibited a stronger orientation toward the discretionary component of corporate responsibility. On the other hand, male board members - in contrast to female directors - were more concerned about economic performance. No significant differences between the two groups were observed with respect to both the legal and ethical dimensions.

\section{Discussion and Conclusion}

An effective board of directors can be one of the firm's major competitive or strategic tools. Although boards of directors have been examined quite extensively, few studies have investigated the board's internal role. The purpose of our study was to extend available research on boards by examining the relationship between the gender of directors and their corporate social responsiveness orientation.

Considerable concern has been expressed in recent years regarding the effectiveness with which board members are discharging their responsibilities. While an active board can be a valuable asset which can contribute to better corporate strategic decision making, we know little about what makes them effective or ineffective.

An interesting aspect of the present study is that it analyzed separately the four components of CSRO. The results reported here reveal that women were less economically oriented and more philanthropically driven than their male counterparts. This finding offers proponents of changes in board composition - particularly regarding the inclusion of more women directors support for their normative suggestions. The data further indicate that both groups had similar orientations toward both the legal and ethical dimensions of corporate responsibility.

Various explanations could be advanced for these results. With respect to the legal component, this finding is not surprising given current trends in society. Numerous laws and extensive government regulation 
Table 2

ANOVAs for Differences Between Female and Male Board Members

\begin{tabular}{|c|c|c|c|}
\hline Dependent Variables & $\begin{array}{l}\text { Females } \\
(n=155)\end{array}$ & $\begin{array}{l}\text { Males } \\
(n=243)\end{array}$ & $\mathrm{F}$ \\
\hline 1. Economic & $\begin{array}{c}3.02 \\
(0.98)\end{array}$ & $\begin{array}{l}3.67 \\
(0.47)\end{array}$ & $78.63 *$ \\
\hline 2. Legal & $\begin{array}{l}2.64 \\
(0.66)\end{array}$ & $\begin{array}{l}2.59 \\
(0.53)\end{array}$ & 0.69 \\
\hline 3. Ethical & $\begin{array}{l}2.38 \\
(0.56)\end{array}$ & $\begin{array}{c}2.29 \\
(0.61)\end{array}$ & 2.19 \\
\hline 4. Philanthropic & $\begin{array}{c}1.83 \\
(0.63)\end{array}$ & $\begin{array}{c}1.43 \\
(0.22)\end{array}$ & $82.32 *$ \\
\hline $\begin{array}{l}a_{\text {Figures }} \text { in parenth } \\
\star p<.001\end{array}$ & standard deviation & & \\
\hline
\end{tabular}

affect virtually every aspect of business activities. They touch "almost every business decision ranging from production of goods and services to their packaging, distribution, marketing, and service" ${ }^{\prime \prime}$. In such an increasingly legalized business environment, corporate executives are fully aware of society's criminal and civil sanctions. The impact of this knowledge on managerial attitudes and behavior has been widely examined and documented in both the popular and academic literature $\mathrm{e}^{37},{ }^{15},{ }^{31}, 10,9$. Indeed, corporate directors are increasingly concerned over the risks of personal legal liability stemming from corporate actions ${ }^{20}{ }^{18}$. The results regarding the ethical orientations of both groups are in line with previous research findings suggesting that a large number of organizations are keenly aware of the importance of ethical behavior, have developed codes of ethics, and are conducting training programs in this area $^{4},{ }^{25}$. It is not surprising, then, that there is general agreement among directors - regardless of their gender - that corporations should be ethical in their behavior and operate within the legal framework.

Concerning the differences between the two groups, one possible explanation for this is that women are simply more inclined to be philanthropically oriented and less sensitive to the firm's economic needs than men. This possibility can never be ruled out but seems implausible. Another possibility is that female directors are more likely to be found in firms that are more economically successful and therefore can afford the luxury of being sensitive to philanthropic needs. A more plausible explanation is that female directors, who are more likely to be outside members, exhibit greater responsiveness to such needs merely because they are outsiders. This view would be consistent with Zahra and Stanton's (1988) finding that boards dominated by outsiders show greater social responsiveness. Indeed, the data show that 74 percent of the women in our sample were outsiders compared to 64 percent of the men. Finally, as another possible explanation, differences in responses may reflect a "generational gap." This study yielded evidence of a significant difference between the ages of the two groups. The women's average age was 42.8 years compared to 53.2 for the men $(\mathrm{t}=32.15, \mathrm{p}<.000)$. Thus, younger directors may hold certain values which are widely different from those of their older counterparts. Future research efforts need to consider more clearly these possible relationships.

Certainly, caveats must be offered regarding the conclusions generated by this research. Board members' CSRO was reported by the directors themselves. Although the study instrument utilized a forced-choice format, the possibility of bias cannot be completely ruled out. However, as a number of authors have pointed out, self-report measures are indispensable in organizational research ${ }^{29}{ }^{11}$. Furthermore, in certain research contexts, self-reports may provide more accurate estimates of population parameters than behavioral measures $^{16}$.

In conclusion, the findings of this study highlight an area of growing concern for both businesses and society. 
The involvement of directors in the strategic process is likely to expand due to the increased risks of legal liability. Moreover, the issue of board members' corporate social responsiveness is likely to gain increased attention because of growing societal demands on corporations and increased emphasis on the ethical dimension of corporate decision making.

\section{Suggestions for Future Research}

Although this study provides interesting new insights into the effects of board members' gender on their corporate social responsiveness orientation, additional research is necessary to determine whether a director's orientation does translate into corporate action. Moreover, since most board decisions are made by committees, in the future researchers may want to investigate the possible impact of group dynamics on member involvement.

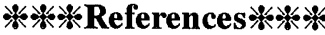

1. Andrews, K. R., "Directors' Responsibility for Corporate Strategy," Harvard Business Review, Vol. 58, pp. 30-42, 1980.

2. Ansberry, C., "The Board Game: More Women are Becoming Directors but it is Still a Token Situation," The Wall Street Journal, p. 29D, March 24, 1986.

3. Aupperle, K., A. Carroll, and J. Hatfield, "An Empirical Examination of the Relationship Between Corporate Social Responsibility and Profitability," Academy of Management Journal, Vol. 28, pp.446465, 1985.

4. Berenbeim, R., "An Outbreak of Ethics," Across the Board, pp. 14-19, 1988.

5. Carroll, A. B., Business and Society, SouthWestern, Cincinnati, Ohio, 1989.

6. Carroll, A. B., "A Three Dimensional Conceptual Model of Corporate Social Performance," Academy of Management Review, Vol. 4, pp. 497-505, 1979.

7. Eisenberg, M., The Structure of the Corporation, Little Brown, Boston, Massachusetts, 1976.

8. Elgart, L. D. "Women on Fortune 500 Boards," California Management Review, Vol.24, pp. 121-127, 1983.

9. Fisher, A., "How to Cut Your Legal Costs," Fortune, pp. 185-192, April 23, 1990.

10. Galen, M., "Guilty! Too Many Lawyers and Too Much Litigation," Business Week, pp. 60-65, April 13, 1992

11. Gupta, N. and T. A. Beehr, "Test of the Correspondence Between Self-Reports and Alternative Data Sources About Work Organizations," Journal of Vocational Behavior, Vol. 20, pp. 1-13, 1982.

12. Hair, J., R. Anderson, and D. Tatham, Multivariate Data Analysis, Macmillan Publishing Company, New York, New York, 1987.
13. Hambrick, D. C. and P. A. Mason, "Upper Echelons: The Organization as a Reflection of Its Top Managers," Academy of Management Review, Vol. 9, pp. 193-206, 1984.

14. Harrigan, K. R., "Numbers and Positions of Women Elected to Corporate Boards," Academy of Management Journal, Vol. 24, pp. 619-625, 1981.

15. Heydinger, R., "Emerging Issues in Risk Management: The Opportunities are Changing," Risk Management, pp. 60, 72-74, September 1987.

16. Howard, G., S. Maxwell, R. Wiener, K. Boynton, and W. Rooney, "Is a Behavioral Measure the Best Estimate of Behavioral Parameters? Perhaps Not," Applied Psychological Measurement, Vol. 4, pp. 293-311, 1980.

17. Ibrahim, N. and J. Angelidis, "Board Member Characteristics and Their Level of Involvement in Strategic Management: A Multivariate Investigation," Proceedings of the Southeast TIMS, pp. 155158, 1990.

18. Janjigian, V. and P. Bloster, "The Elimination of Director Liability and Stockholder Returns: An Empirical Investigation," Journal of Financial Research, Vol. 13, pp. 53-60, 1990.

19. Kesner, I. F., "Directors' Characteristics and Committee Membership: An Investigation of Type, Occupation, Tenure, and Gender," Academy of Management Journal, Vol. 31, pp. 66-84, 1988.

20. Kesner, I. F. and R. B. Johnson, "Crisis in the Boardroom: Fact and Fiction," Academy of Management Executive, pp. 23-35, 1990.

21. Kesner, I. F. and D. E. Dalton, "Boards of Directors and the Checks and (IPM) Balances of Corporate Governance," Business Horizons, Vol. 5, pp. 17-23, 1986.

22. Kesner, I. F., B. Victor, and B. LaMont, "Board Composition and the Commission of Illegal Acts: An Investigation of Fortune 500 Companies," Academy of Management Journal, Vol. 29, pp. 789-799, 1986.

23. LaFraniere, S., "The Babe in the S\&L Woods: What Didn't Neil Bush Know?" The Washington Post National Weekly Edition, pp. 6-7, 1990.

24. Leontiades, M., "Choosing the Right Manager to Fit the Strategy," The Journal of Business Strategy, Vol. 3, pp. 58-69, Fall 1982.

25. Loucks, V. R., Jr., "A CEO Looks at Ethics," Business Horizons, pp. 2-6, March-April 1987.

26. Nunnaly, J., Introduction to Psychological Measurement, McGraw-Hill, New York, New York, 1970.

27. O'Neill, H., C. Saunders, A. and McCarthy, A., "Board Members Background Characteristics and Their Level of Corporate Social Responsiveness: A Multivariate Investigation," Academy of Management Best Papers Proceedings, pp. 32-36, 1989. (1989):

28. Pfeffer, J. and G. R. Salancik, The External Control of Organizations: A Resource Dependence Perspective, Harper \& Row, New York, New York, 1978. 
29. Podsakoff, P. and D. Organ, "Self-Reports in Organizational Research: Problems and Prospects," Journal of Management, Vol. 12, pp. 531-544, 1986.

30. Rogan, H., "Women Executives Feel That Men Both Aid and Hinder Their Careers," The Wall Street Journal, p. 35, October 29, 1984.

31. Samuelson, S., "The Changing Relationship Between Managers and Lawyers," Business Horizons, pp. 21-27, September-October 1990.

32. Schwartz, F. N., "Invisible Resource: Women for Boards," Harvard Business Review, Vol. 58, pp. 6-18, 1980.

33. Smith, W. and R. Blackburn, "Corporate Social Responsibility: A Psychometric Examination of a Measurement Instrument," Proceedings of the Southern Management Association, pp. 293-295, 1988.

34. Stultz, J. E., "Madam Director," Directors and Boards, pp. 6-19, 1979. p73

35. Ungson, G., C. James, B. and Spicer, "The Effects of Regulatory Agencies on Organizations in Wood Products and High Technology/Electronics Industries," Academy of Management Journal, Vol. 28, pp. 426-445, 1985.

36. Vance, S. C., "Corporate Governance: Assessing Corporate Performance by Boardroom Attributes," Journal of Business Research, Vol. 6, pp. 203-220, 1978.

37. Whitehill, A., "American Executives Through Foreign Eyes," Business Horizons, pp. 42-48, MayJune 1989.

38. Zahra, S. and W. Stanton, "The Implications of Board of Directors' Composition For Corporate Strategy and Performance," International Journal of Management, Vol. 5, pp. 229-236, 1988. 